\title{
HUBUNGAN INDUSTRIAL DALAM AKSI MOGOK KERJA OLEH SERIKAT PEKERJA DI PT. ULTRAJAYA MILK INDUSTRY \& TRADING COMPANY
}

\author{
Ellyna Putri Nugraha ${ }^{1}$, Hollyness N. Singadimedja ${ }^{2}$ \\ Fakultas Hukum Universitas Padjadjaran \\ DOI : https://doi.org/ 10.29313/shjih.v19i1.6991
}

\begin{abstract}
ABSTRAK
PT. Ultrajaya Milk Industry \& Trading Company mengalami perselisihan hubungan industrial dengan serikat pekerja sehingga berdampak pada terjadinya aksi mogok kerja oleh serikat pekerja. Tujuannya mengkaji aspek hukum hubungan industrial dalam penyelesaian sengketa aksi mogok kerja di Indonesia juga untuk menemukan solusi terhadap penyelesaian perselisihan hubungan industrial antara PT. Ultrajaya Milk Industry \& Trading Company dengan serikat pekerja. Akibat tindakan serikat pekerja Peradilan memutuskan Serikat Pekerja dan Pengurus Serikat Pekerja telah melakukan mogok tidak sah dan melakukan Perbuatan Melawan Hukum serta PT. Ultrajaya Milk Industry \& Trading Company tidak mendapatkan ganti kerugian sembilan belas miliyar seperti yang dimintakan dalam gugatannya.
\end{abstract}

Kata Kunci: Hubungan Industrial; Sengketa Hubungan Industrial; Mogok Kerja.

\begin{abstract}
PT. Ultrajaya Milk Industry \& Trading Company experienced an industrial relations dispute with a labor union which resulted in a strike by the union. The aim is to examine the legal aspects of industrial relations in the settlement of disputes on strike action in Indonesia as well as to find solutions for the settlement of industrial relations disputes between PT. Ultrajaya Milk Industry \& Trading Company with trade unions. As a result of the trade union's actions, the Judiciary decided that the Workers 'Union and Workers' Union Administrators had conducted illegal strikes and committed illegal acts and PT. Ultrajaya Milk Industry \& Trading Company did not get nineteen billion compensation as requested in the lawsuit.
\end{abstract}

Keywords: Industrial relations; Industrial Relations Dispute Settlement; Strike. 


\section{Pendahuluan}

Negara hukum menjaga ketertiban dengan harapan agar semuanya berjalan menurut hukum dalam konteks Indonesia, maka dikenal dengan Negara hukum Pancasila. Indonesia sebagai negara yang berkembang melaksanakan pembangunan di bidang hukum khususnya terkait ketenagakerjaan yang sangat diharapkan oleh masyarakat Indonesia baik oleh pekerja maupun oleh pengusaha atau pemberi kerja. Pembangunan tenaga kerja berperan untuk meningkatkan produktivitas nasional dan kesejahteraan masyarakat yang oleh karenanya, tenaga kerja harus diperhatikan dan diberdayakan agar mereka memiliki nilai lebih dalam arti lebih berkualita dan mampu untuk bekerja guna memenuhi kebutuhan hidupnya juga keluarganya. Selain itu, permberdayaan pekerja secara optimal mampu mewujudkan cita cita negara dalam pembangunan nasional dan mampu bersaing dalam era global. Hal tersebut merupakan bagian dari pembangunan nasional yang dilaksanakan dalam rangka pembangunan manusia Indonesia seutuhnya dan pembangunan masyarakat Indonesia seluruhnya untuk meningkatkan harkat dan martabat tenaga kerja. Pembangunan ketenagakerjaan dilaksanakan untuk mewujudkan manusia dan masyarakat Indonesia yang sejahtera, adil, makmur dan merata, baik materiil maupun spiritual. Pembangunan di bidang hukum ketenagakerjaan tidak terlepas dari ekonomi masyarakat. Roda ekonomi akan selalu berputar yang akan mengakibatkan pasang surut ekonomi masyarakat.

Perusahaan atau pemberi kerja merupakan part of the ring dari roda perekonomian. Dapat dikatakan sebagai mesin penggerak roda perkonomian yang sangat berpengaruh terhadap pembangunan di bidang hukum ketenagakerjaan. Dalam perusahaan tersebut terdapat hubungan industrial yang terjadi antara pengusaha dan pekerja. Didalamnya harus saling kerjasama, koordinasi, dengan tujuan yang sama yaitu untuk mendapatkan keuntungan yang tentu saja secara tidak langsung memutar roda perekonomian itu sendiri. Pemerintah melakukan upaya agar pembangunan di bidang ketenagakerjaan sesuai seperti yang diharapkan oleh masyarakat yaitu dengan adanya Undang - undang Nomor 13 Tahun 2003 yang selanjutnya disebut dengan Undang - undang Ketenagakerjaan. Dalam Undang undang Ketenagakerjaan pengertian hubungan industrial menyebutkan bahwa, 
"Hubungan industrial adalah suatu sistem hubungan yang terbentuk antara para pelaku dalam proses produksi barang dan/atau jasa yang terdiri dari unsur pengusaha, pekerja/buruh, dan pemerintah yang didasarkan pada nilai nilai Pancasila dan Undang Undang Dasar Negara Republik Indonesia Tahun 1945”. Kondisi hubungan industrial ideal mempunyai beberapa faktor pendukung salah satunya komunikasi yang baik antar para pelaku seperti pemberi kerja, pekerja juga pemerintah agar terhindar dari hal - hal yang tidak diinginkan seperti aksi mogok kerja. Tujuannya untuk membangun dan memupuk hubungan industrial yang kondusif, harmonis, dan berkeadilan di lingkungan kerja.

Hubungan industrial tidak selalu berjalan secara mulus. Bervariasinya permasalahan yang menimbulkan konflik, tentunya tidak selalu dapat diselesaikan dalam waktu yang sesingkat - singkatnya dengan hasil dari pemecahan masalah yang dapat diterima bagi para pihak yang berselisih, bahkan tidak jarang berujung pada munculnya sengketa. Ada berbagai faktor yang memicu terjadinya perselisihan antara pekerja dengan pemberi kerja. Oleh karena itu, pemerintah mengatur lebih lanjut mengenai hubungan industrial yaitu dengan adanya UndangUndang Nomor 2 tahun 2004 tentang Penyelesaian Perselisihan Hubungan Industrial yang selanjutnya disebut dengan UU PPHI. Dalam Pasal 1 angka 1 UU PPHI memberikan definisi perselisihan hubungan industrial sebagai berikut, "perbedaan pendapat yang mengakibatkan pertentangan antara pengusaha atau gabungan pengusaha dengan pekerja/buruh atau serikat pekerja/serikat buruh karena adanya perselisihan mengenai hak, perselisihan kepentingan, perselisihan pemutusan hubungan kerja dan perselisihan antar serikat pekerja/serikat buruh dalam satu perusahaan".

Berdasarkan Pasal 1 angka 1 UU PPHI terdapat unsur - unsur yang menyebutkan macam perselisihan industrial antara lain, perselisihan mengenai hak, perselisihan kepentingan, perselisihan pemutusan hubungan kerja dan perselisihan antar serikat pekerja/serikat buruh dalam satu perusahaan. Pengadilan yang berwenang memeriksa, mengadili dan memberi putusan terhadap perselisihan hubungan industrial disebut Pengadilan Hubungan Industrial. 
Berkaitan dengan perselisihan hubungan industrial, dalam prakteknya timbul perselisihan hubungan industrial yang terjadi antara PT. Ultrajaya Milk Industry \& Trading Company dengan Pimpinan Unit Kerja "Serikat Pekerja" Rokok Tembakau Makanan dan Minuman Serikat Pekerja Seluruh Indonesia yang selanjutnya disebut PUK SP RTMM-SPSI. Perselisihan hubungan industrial itu bermula dari PT. Ultrajaya Milk Industry \& Trading Company memenangi sidang Pengadilan Hubungan Industrial atau PHI yang berdampak pada terjadinya aksi mogok kerja ratusan karyawannya yang mengakibatkan kerugian sebesar kurang lebih 19 Milyar yang diderita oleh PT. Ultrajaya Milk Industry \& Trading Company. Aksi mogok kerja yang dilakukan oleh PUK SP RTMM-SPSI karena karyawan menuntut perusahaan memberlakukan lagi kebijakan pensiun $2+1$, batas usia pensiun sesuai Peraturan Pemerintah Nomor 45 Tahun 2015, mengadakan gathering, dan tidak ada outsourcing di corebusiness (OMS dan CMS). Upaya penyelesaian sengketa ini sudah pernah dilakukan secara bipartite dan tripartite, tapi hasilnya gagal. Bahkan, Dinas Tenaga Kerja (Disnaker) sempat mengeluarkan surat anjuran dengan beberapa rekomendasi, namun tetap tidak menemukan kesepakatan. Aksi mogok kerja itu mengakibatkan beberapa mesin produksi tidak berfungsi, bahan baku terganggu, pengiriman barang terhambat, serta lalu lintas di depan perusahaan menjadi macet. PT. Ultrajaya Milk Industry \& Trading Company melayangkan gugatan perdata ke Pengadilan Negeri Bale Bandung untuk menuntut PUK dan pengurusnya terhadap apa yang mereka lakukan meskipun sejauh ini mereka masih diperbolehkan bekerja. Berdasarkan hal tersebut permasalahan hukum yang timbul adalah bagaimana aspek hukum hubungan industrial dalam penyelesaian sengketa terkait aksi mogok kerja di Indonesia? Kemudian bagaimana penyelesaian perselisihan hubungan industrial antara PUK SP RTMM-SPSI (Pimpinan Unit Kerja “Serikat Pekerja” Rokok Tembakau Makanan dan Minuman Serikat Pekerja Seluruh Indonesia) dengan PT. Ultrajaya Milk Industry \& Trading Company atas gugatan rekonpensinya menuntut penggantian kerugian perusahaan atas mogok kerja sebesar 19 milyar rupiah. 


\section{Metode Penelitian}

Penelitian ini menggunakan metode pendekatan yuridis normatif dengan spesifikasi penelitian deskriftif analitis, yang berasal dari bahan-bahan pustaka lazimnya dinamakan data sekunder yang menggambarkan bahan hukum primer bahan hukum sekunder dan bahan hukum tersier. Penelitian ini menggunakan pendekatan perundang-undangan dan pendekatan kasus. Pendekatan perundangundangan digunakan untuk mengetahui keseluruhan peraturan hukum yang berkaitan dengan aspek Ketenagakerjaan. Pendekatan kasus bertujuan untuk mengetahui serta memahami penerapan aturan - aturan atau kaidah hukum yang dilakukan dalam praktik hukum. Selanjutnya dilakukan analisis terhadap hasil penelitian dengan menggunakan peraturan perundang-undangan dan teori yang relevan.

\section{Hasil dan Analisis}

\section{Aspek hukum hubungan industrial dalam penyelesaian sengketa terkait aksi mogok kerja di Indonesia.}

Setiap perusahaan pasti melakukan hubungan hukum yang dilakukan antara pemberi kerja dan pekerja. Ada kalanya perusahaan mengalami perselisihan hubungan industrial seperti melakukan aksi mogok kerja. Merujuk pada peraturan perundang - undangan seperti yang terdapat dalam Pasal 1 angka 23 Undang undang Ketenagakerjaan menyebutkan bahwa, mogok kerja adalah tindakan pekerja/buruh yang direncanakan dan dilaksanakan secara bersama-sama dan/atau oleh serikat pekerja/serikat buruh untuk menghentikan atau memperlambat pekerjaan. Pemogokan didefinisikan sebagai tindakan yang dilakukan oleh pekerja terhadap pengusaha dengan tujuan menekan pengusaha atau perusahaan untuk memenuhi tuntutannya atau sebagai tindakan solidaritas untuk teman sekerja lainnya. Mogok kerja merupakan hak dasar pekerja/buruh dan/atau serikat pekerja/serikat buruh yang dilakukan secara sah, tertib, dan damai sebagai akibat gagalnya perundingan. Yang dimaksud dengan tertib dan damai adalah tidak mengganggu keamanan dan ketertiban umum, dan/atau mengancam keselamatan jiwa dan harta benda milik perusahaan atau pengusaha atau orang lain atau milik masyarakat. Hal tersebut dilakukan oleh PUK SP RTMM - SPSI oleh beberapa 
pekerja yang bekerja di PT. Ultrajaya Milk Industry \& Trading Company. Menurut Pasal 140 ayat (1) Undang - undang Ketenagakerjaan menyebutkan bahwa, sekurang-kurangnya dalam waktu 7 (tujuh) hari kerja sebelum mogok kerja dilaksanakan, pekerja/buruh dan serikat pekerja/serikat buruh wajib memberitahukan secara tertulis kepada pengusaha dan instansi yang bertanggung jawab di bidang ketenagakerjaan setempat. Karenanya seperti yang ada dalam Pasal 141 menyebutkan bahwa terdapat aturan yang mewajibkan pihak perusahaan maupun instansi pemerintah untuk memberikan tanda terima atas pemberitahuan tertulis mogok kerja yang diajukan.

Dalam hal ini pada saat mogok kerja yang dilakukan oleh PUK SP RTMMSPSI merupakan sikap tidak menghormati proses dan upaya hukum yang sedang berjalan dalam tingkat tripartit di Dinas Tenaga Kerja dan Transmigrasi Kabupatren Bandung Barat yang tidak menghargai sikap hukum atas PT. Ultrajaya Milk Industry \& Trading Company atas penolakan kedua surat anjuran yang timbul atas terjadinya perselisihan antara PT. Ultrajaya Milk Industry \& Trading Company dengan PUK SP RTMM - SPSI di tingkat tripartit. Mogok kerja yang dilakukan PUK SP RTMM - SPSI dapat dikatakan mogok kerja tidak sah karena penolakan tersebut berdampak kepada PUK SP RTMM - SPSI yang akhirnya melakukan mogok kerja yang seharusnya apabila ada ketidakpuasan terhadap sikap hukum atas penolakan tersebut, PUK SP RTMM - SPSI untuk mengajukan upaya hukum penyelesaian perselisihan dengan mengajukan gugatan ke Pengadilan Hubungan Industrial pada Pengadilan Negeri Bandung Kelas 1A Khusus sesuai dengan ketentuan Pasal 14 UU PPHI dan bukan untuk melakukan mogok kerja. Pasal 14 UU PPHI yang menyebutkan:

(1) Dalam hal anjuran tertulis sebagaimana dimaksud dalam Pasal 13 ayat (2) huruf a ditolak oleh salah satu pihak, maka para pihak dapat melanjutkan penyelesaian perselisihan ke Pengadilan Hubungan Industrial pada Pengadilan Negeri Setempat.

(2) Penyelesaian perselisihan sebagaimana dimaksud dalam ayat (1) dilaksanakan dengan pengajuan gugatan oleh salah satu pihak di Pengadilan Hubungan Industrial pada Pengadilan Negeri Setempat. 
Menurut Pasal 3 Keputusan Menteri Tenaga Kerja dan Transmigrasi Republik Indonesia Nomor: 232/MEN/2003 Tentang Akibat Hukum Mogok Kerja Yang Tidak Sah selanjutnya disebut Kepmenakertrans 232/2003, mogok kerja sah apabila:

a. Akibat gagalnya perundingan; dan/atau

Yang dimaksud dengan gagalnya perundingan adalah tidak tercapainya kesepakatan penyelesaian perselisihan hubungan industrial yang dapat disebabkan karena pengusaha tidak mau melakukan perundingan perundingan walaupun serikat pekerja/serikat buruh atau pekerja/buruh telah meminta secara tertulis kepada pengusaha 2 (dua) kali dalam tenggang waktu 14 (empat belas) hari kerja atau perundingan mengalami jalan buntu yang dinyatakan oleh para pihak dalam risalah perundingan.

b. Dengan pemberitahuan tertulis kepada perusahaan dan Dinas Ketenagakerjaan; dan/atau

c. Pemberitahuan tertulis tersebut sekurang-kurangnya disampaikan 7 hari sebelum pelaksanaan mogok kerja; dan/atau

d. Pemberitahuan tertulis tersebut sekurang-kurangnya memuat:

1) Waktu (hari, tanggal dan jam) dimulai dan diakhirnya mogok kerja;

2) Tempat mogok kerja;

3) Alasan/sebab-sebab mogok kerja;

4) Tanda tangan ketua dan sekretaris dan/atau masing-masing ketua dan sekretaris serikat pekerja/buruh sebagai penanggung jawab mogok kerja.

Berkaitan dengan perselisihan hubungan industrial yang terjadi antara PT. Ultrajaya Milk Industry \& Trading Company dengan PUK SP RTMM-SPSI berdampak kepada mogok kerja yang dilakukan oleh PUK SP RTMM-SPSI mendasarkan tuntutannya yaitu meminta PT. Ultrajaya Milk Industry \& Trading Company untuk melaksanakan acara tahunan temu akrab yang sudah menjadi kebiasaan setiap tahunnya dan melibatkan keluarga serta jangan ada peraturan perusahaan di atas perjanjian kerja bersama sesuai dengan amanah Undang undang Ketenagakerjaan. Merujuk pada Pasal 3 Kepmenakertrans 232/2003 di atas, 
hal tersebut merupakan tindakan yang bertentangan dengan hukum, karena tuntutan tersebut sama sekali belum pernah dirundingkan antara PT. Ultrajaya Milk Industry \& Trading Company dengan PUK SP RTMM-SPSI, artinya belum dapat dikategorikan sebagai gagal perundingan.

Terhadap aksi mogok kerja yang dilakukan tentulah akan mempunyai dampak atau konsekuensi. Konsekuensi bila menghalangi mogok kerja yang sah, tertib, dan damai yaitu termuat dalam Pasal 143 ayat (1) Undang - undang Ketenagakerjaan. Siapapun tidak boleh menghalang-halangi mogok kerja yang sah, tertib, dan damai. Yang dimaksud dengan menghalang-halangi antara lain dengan cara:

a. menjatuhkan hukuman;

b. mengintimidasi dalam bentuk apapun; atau

c. melakukan mutasi yang merugikan.

Diatur lebih jelas dalam Pasal 143 ayat (2) Undang - undang Ketenagakerjaan menyebutkan bahwa apabila suatu mogok kerja terlaksana dengan sah, tertib, dan damai; maka siapapun dilarang melakukan penangkapan dan/atau penahanan terhadap pekerja/buruh dan pengurus serikat pekerja/serikat buruh yang melakukan mogok kerja tersebut. Dengan menggunakan teori hukum: penafsiran terbalik (a contrario), maka ketentuan tersebut dapat ditafsirkan bahwa jika suatu mogok kerja tidak sah, tertib, dan damai, maka aparat keamanan tidak dilarang untuk melakukan penangkapan dan/atau penahanan terhadap pekerja dan pengurus serikat pekerja tersebut. Pasal 185 ayat (1) jo. Pasal 143 menyebutkan bahwa sanksi bila menghalang-halangi mogok kerja yang sah, tertib, dan damai adalah pidana penjara paling singkat 1 (satu) tahun dan paling lama 4 (empat) tahun dan/atau denda paling sedikit Rp 100 juta dan paling banyak Rp 400 juta.

Terhadap mogok kerja yang dilakukan secara tidak sah pun pasti mempunyai konsekuensi, Pasal 14 ayat (4) Undang - undang Ketenagakerjaan menyebutkan bahwa dalam hal mogok kerja dilakukan tanpa pemberitahuan tertulis kepada perusahaan dan dinas ketenagakerjaan setidaknya 7 hari sebelum dilaksanakan, maka demi menyelamatkan alat produksi dan asset perusahaan, perusahaan dapat mengambil tindakan sementara dengan melarang mogok kerja di 
lokasi kegiatan proses produksi atau bahkan di lokasi perusahaan bila dianggap perlu. Begitu juga jika mogok kerja dilakukan secara tidak sah, maka pekerja/buruh yang melakukan mogok kerja tersebut dapat dikualifikasikan sebagai mangkir oleh perusahaan seperti yang sudah diatur dalam Pasal 6 ayat (1) Kepmenakertrans 232/2003. Pemanggilan untuk kembali bekerja bagi pelaku mogok kerja dilakukan oleh perusahaan 2 kali berturut-turut dalam tenggang waktu 7 (tujuh) hari dalam bentuk pemanggilan secara patut dan tertulis. Pekerja/buruh yang tidak memenuhi panggilan ini dianggap mengundurkan diri secara sukarela. Dan untuk pengunduran diri tersebut ini perusahaan tidak perlu melalui proses Pemutusan Hubungan Kerja ("PHK") sebagaimana ditetapkan dalam UU PPHI. Dalam hal demikian, perusahaan dapat mengenakan sanksi disiplin kepada pekerja/buruh berdasarkan aturan perusahaan.

Berkaitan dengan perselisihan hubungan industrial yang terjadi antara PT. Ultrajaya Milk Industry \& Trading Company dengan PUK SP RTMM-SPSI, mogok kerja yang dilakukan berbentuk tekanan dan paksaan kepada PT. Ultrajaya Milk Industry \& Trading Company untuk memenuhi tuntutan PUK SP RTMMSPSI. Dari perselisihan yang terjadi antara kedua belah pihak bahwa tidak ada satupun hak normatif pekerja baik yang diatur dalam Perjanjian Kerja Bersama maupun hak normatif yang diatur dalam Undang - undang Ketenagakerjaan yang telah dilanggar ataupun dikurangi oleh PT. Ultrajaya Milk Industry \& Trading Company. Mogok kerja yang dilakukan oleh PUK SP RTMM-SPSI merupakan gambaran ketidakpatuhan, tidak menghormati proses dan upaya hukum yang sedang berjalan dalam tingkat tripartit di Dinas Tenaga Kerja dan Transmigrasi Kabupaten Bandung Barat.

2. Penyelesaian perselisihan hubungan industrial antara PT. Ultrajaya Milk Industry \& Trading Company dengan PUK SP RTMM-SPSI (Pimpinan Unit Kerja "Serikat Pekerja" Rokok Tembakau Makanan dan Minuman Serikat Pekerja Seluruh Indonesia) PT. Ultrajaya Milk Industry \& Trading Company.

Perselisihan hubungan industrial yang terjadi antara PT. Ultrajaya Milk Industry \& Trading Company dengan PUK SP RTMM-SPSI (Pimpinan Unit Kerja 
"Serikat Pekerja" Rokok Tembakau Makanan dan Minuman Serikat Pekerja Seluruh Indonesia) terjadi setelah beberapa bulan Perjanjian Kerja Bersama atau PKB yang dilakukan oleh kedua belah pihak mengalami perselisihan dimana pekerja yang diwakili oleh serikat pekerja menuntut penggugat untuk:

a. Kembalikan kebijakan perusahaan terkait pensiun $2+1$ ketentuan yang sudah menjadi kebiasaan sebelum adanya kesepakatan;

b. Meminta penetapan batas maksimum usia pensiun sesuai PP 45 Tahun 2015;

c. Memasukan batas usia pensiun pada Perjanjian Kerja Bersama (PKB) sesuai dengan kesepakatan bersama;

d. Outsourcing di corebusiness (OMS dan CMS).

Yang sebelumnya bahwa seluruh hak - hak normative pekerja sebagaimana diatur baik dalam Perjanjian Kerja Bersama Nomor: KEP. 506/005/HIS/PKB/VI/2017 maupun hak normative yang diatur dalam Undang - undang Nomor 13 Tahun 2003 tentang Ketenagakerjaan, tidak ada satupun yang dikurangi, seluruhnya telah dipenuhi oleh PT. Ultrajaya Milk Industry \& Trading Company. Terhadap perselisihan tersebut kedua belah pihak telah beberapa kali melakukan perundingan guna penyelesaian secara bipartit namun gagal, kemudian dilanjutkan secara tripartit oleh Dinas Tenaga Kerja dan Transmigrasi Kabupaten Bandung Barat yang selanjutnya disebut disnakertrans dengan mengeluarkan dua surat anjuran yaitu:

a. Surat Anjuran No. 506/712/HIS/VII/2018, tanggal 20 Agustus 2018, yang isinya yaitu:

1) Agar pihak pekerja dan pihak pengusaha melakukan perundingan pembahasan tentang ketentuan usia pensiun sebagai pedoman pemutusan hubungan kerja bagi pekerja yang sudah memasuki usia pensiun dan menuangkan hasil perundingan tersebut di dalam perjanjian kerja bersama;

2) Agar pihak pengusaha tetap memberlakukan ketentuan yang tercantum didalam surat pihak pengusaha tertanggal 4 September 2014 perihal 
Pensiun sebelum terjadinya kesepakatan perundingan tentang usia pensiun;

3) Agar kedua belah pihak memberikan jawaban atas anjuran ini selambat - lambatnya dalam jangka waktu 10 hari kerja setelah diterimanya anjuran ini.

b. Surat Anjuran No. 506/339/HIS/V/2018, yang kemudian diganti dengan Surat Anjuran No. 506/404/HIS/V/2018, tanggal 24 Mei 2018, yang isinya yaitu:

1) Agar pihak pengusaha tetap memperkerjakan pekerja/operator regular untuk menjalankan mesin apabila ada pekerja/operator regular yang tidak masuk kerja;

2) Agar pihak pengusaha berkoordinasi dengan pihak Pengawas Ketenagakerjaan Balai Pelayanan Pengawas Ketenagakerjaan Wilayah IV Dinas Tenaga Kerja dan Transmigrasi Provinsi Jawa Barat, sebagaimana hasil akhir Nota Pemeriksaan Khusus yang telah diterbitkan;

3) Agar kedua belah pihak memberikan jawaban atas anjuran ini selambat - lambatnya dalam jangka waktu 10 hari kerja setelah diterimanya anjuran ini.

Berdasarkan kedua surat anjuran Disnakertrans diatas, PT. Ultrajaya Milk Industry \& Trading Company seluruhnya menolak sedangkan serikat pekerja menerimanya. Atas penolakan tersebut, para pekerja yang diwakili oleh Serikat Pekerja untuk memenuhi tuntutan tersebut melakukan beberapa aksi diantaranya:

a. Melakukan unjuk rasa pada tanggal 24 Mei 2018 bertempat di Area Parkir Disnakertrans Kabupaten Bandung Barat dengan tuntutan untuk keluarkan segera anjuran terkait OMS dan CMS.

b. Melakukan aksi mogok kerja pada tanggal 12-13 September 2018 bertempat di Area Parkir Halaman Depan PT. Ultrajaya Milk Industry \& Trading Company. Pada tanggal 12 September 2018 terdapat 475 pekerja yang 
mengikuti aksi mogok kerja, sedangkan pada tanggal 13 September 2018 terdapat 477 pekerja yang mengikuti aksi mogok kerja dengan tuntutan:

1) Kembalikan kebijakan perusahaan terkait pensiun $2+1$ ketentuan yang sudah menjadi kebiasaan sebelum adanya kesepakatan;

2) Meminta penetapan batas maksimum usia pensiun sesuai PP 45 Tahun 2015;

3) Memasukan batas usia pensiun pada Perjanjian Kerja Bersama (PKB) sesuai dengan kesepakatan bersama;

4) Segera dilaksanakan Acara Tahunan Temu Akrab yang sudah menjadi kebiasaan setiap tahunnya dan melibatkan keluarga;

5) Jangan ada outsourcing di corebussines (OMS dan CMS) sesuai dengan peraturan perundang - undangan dan segera laksanakan sesuai nota pemeriksaan dari pengawasan Disnakertrans Jabar dan Anjuran hasil mediasi dengan Disnakertrans;

6) Jangan ada Peraturan Perusahaan di atas Perjanjian Kerja Bersama sesuai dengan amanah Undang - undang Ketenagakerjaan 13 Tahun 2003.

Demikian juga dengan mogok kerja yang dilakukan oleh pekerja pada tanggal 12-13 September 2018 yang mendasarkan tuntutannya untuk segera dilaksanakan acara tahunan temu akrab yang sudah menjadi kebiasaan setiap tahunnya dan melibatkan keluarga, juga jangan ada peraturan perusahaan diatas perjanjian kerja bersama sesuai dengan amanah Undang - undang Ketenagakerjaan. Hal tersebut sudah jelas merupakan tindakan yang bertentangan dengan hukum karena tuntutan tersebut sama sekali belum pernah dirundingkan antara kedua belah pihak yang artinya belum dapat dikategorikan sebagai gagal perundingan.

Kedua aksi yang dilakukan oleh serikat pekerja yaitu aksi unjuk rasa dan aksi mogok kerja sangat tidak berdasar hukum yang hanya berupa tekanan dan secara tidak langsung adalah bentuk pemaksaan kepada PT. Ultrajaya Milk Industry \& Trading Company untuk memenuhi kehendak para pekerja yang diwakili oleh serikat pekerja. Secara jelas tidak ada satu pun hak - hak normative pekerja baik yang diatur dalam PKB maupun hak - hak normative pekerja yang diatur di dalam 
Undang - undang Ketenagakerjaan telah dilanggar ataupun dikurangi oleh PT. Ultrajaya Milk Industry \& Trading Company. Kedua aksi tersebut juga merupakan gambaran ketidakpatuhan, tidak menghormati proses dan upaya hukum yang sedang berjalan dalam tingkat Tripartit di Disnakertrans Kabupaten Bandung Barat, serta tidak menghargai sikap hukum daripada PT. Ultrajaya Milk Industry \& Trading Companyatas penolakan kedua surat anjuran tanggal 24 Mei 2018 oleh Disnakertrans Kabupaten Bandung Barat.

Ketidakpuasan dari serikat pekerja terhadap sikap hukum atas penolakan kedua surat anjuran tersebut seharusnya mengajukan upaya hukum penyelesaian perselisihan dengan mengajukan gugatan ke Pengadilan Hubungan Industrial pada Pengadilan Negeri Bandung Kelas 1A Khusus yang sesuai dengan ketentuan Pasal 14 Undang - undang Nomor 2 Tahun 2004 tentang Penyelesaian Perselisihan Hubungan Industrial yang menyebutkan bahwa:

a. Dalam hal anjuran tertulis sebagaimana dimaksud dalam pasal 13 ayat (2) huruf a ditolak oleh salah satu pihak, maka para pihak dapat melanjutkan penyelesaian perselisihan ke Pengadilan Hubungan Industrial pada Pengadilan Negeri setempat.

b. Penyelesaian perselisihan sebagaimana dimaksud dalam ayat (1) dilaksanakan dengan pengajuan gugatan oleh salah satu pihak di Pengadilan Hubungan Industrial pada Pengadilan Negeri setempat.

Tindakan unjuk rasa yang dilakukan pada tanggal 24 Mei 2018 dan mogok kerja pada tanggal 12-13 September 2018 yang dilakukan oleh serikat pekerja telah adanya intimidasi, penghasutan dengan menghalang - halangi beberapa orang pekerja baik yang merupakan anggota maupun pekerja diluar anggota PUK SP RTMM-SPSI, untuk tidak bekerja dan menolak kerja lembur yang telah dijadwalkan oleh PT. Ultrajaya Milk Industry \& Trading Company. Adanya bentuk intimidasi, penghasutan, dan penghalang - halangan yang dilakukan sudah jelas merupakan pelanggaran hukum. Sehingga PT. Ultrajaya Milk Industry \& Trading Company meragukan aksi mogok kerja yang dilakukan pada tanggal 12-13 September 2018 itu tidak murni karena kemauan secara sukarela dari para pekerja itu sendiri, namun karena ketakutan atas tekanan intimidasi/penghasutan oleh PUK 
SP RTMM-SPSI yang bertentangan dengan Pasal 138 (1) Undang - undang Ketenagakerjaan menyebutkan bahwa pekerja/buruh dan/atau serikat pekerja/serikat buruh yang bermaksud mengajak pekerja/buruh lain untuk mogok kerja pada saat mogok kerja berlangsung dilakukan dengan tidak melanggar hukum.

PT. Ultrajaya Milk Industry \& Trading Company tetap membayarkan seluruh gaji pekerja dengan alasan untuk menjaga kondusifitas perusahaan sekalipun aksi mogok kerja yang dilakukan oleh serikat pekerja tidak sah. Tindakan mogok kerja dengan adanya bentuk intimidasi, penghasutan dan penghalang - halangan tersebut bertentangan dengan Undang - undang Ketenagakerjaan j.o Keputusan Menteri Tenaga Kerja dan Transmigrasi Nomor KEP.232/MEN/2003 tentang Akibat Hukum Mogok Kerja Yang Tidak Sah. Sehingga tindakan tersebut dapat dikualifikasikan sebagai perbuatan melawan hukum atau onrechtmatigedaad sebagaimana dalam Pasal 1365 KUHPerdata, yang telah mengakibatkan kerugian baik materiil maupun immaterial (moril) terhadap PT. Ultrajaya Milk Industry \& Trading Company.

Akibat tindakan aksi mogok kerja yang dilakukan oleh para pekerja telah mengakibatkan kerugian yang dialami oleh PT. Ultrajaya Milk Industry \& Trading Company, baik immaterial (nama baik) dan kerugian materiil yaitu terhentinya produksi, penjualan (order pembelian costumer tidak bisa dikirimkan) dan pembayaran gaji selama mogok kerja. Mengingat status dan kemampuan PUK SP RTMM-SPSI selaku pekerja, tentunya tidak akan mampu mengganti kerugian immaterial yang dialami oleh PT. Ultrajaya Milk Industry \& Trading Company selaku pengusaha, maka PT. Ultrajaya Milk Industry \& Trading Company membebaskan pengurus PUK SP RTMM-SPSI untuk mengganti kerugian tersebut. Akibat perbuatan melawan hukum yang dilakukan oleh pengurus PUK SP RTMM - SPSI telah menimbulkan kerugian materiil bagi PT. Ultrajaya Milk Industry \& Trading Company yang kurang lebih mencapai sembilan belas miliyar sebagai dampak dari aksi mogok kerja yang dilakukan membuat berhentinya proses produksi, berhentinya penjualan, dan pembayaran gaji. Untuk mengganti kerugian tersebut maka sewajarnya pengurus PUK SP RTMM-SPSI untuk bertanggungjawab dengan cara tanggung renteng untuk mengganti seluruh 
kerugian materiil yang di alami oleh PT. Ultrajaya Milk Industry \& Trading Company dengan memotong sebesar 50\% dari gaji yang diterima pengurus PUK RTMM SPSI setiap bulannya selama bekerja di PT. Ultrajaya Milk Industry \& Trading Company. Pengadilan Hubungan Industrial memutuskan bahwa Tergugat I ialah PUK SP RTMM - SPSI dan Tergugat II ialah Pengurus PUK SP RTMM SPSI telah melakukan Perbuatan Melawan Hukum dan PT. Ultrajaya Milk Industry \& Trading Company tidak mendapatkan pertanggungjawaban ganti kerugian sebesar kurang lebih Sembilan belas miliyar tersebut dari Tergugat I dan Tergugat II yaitu PUK SP RTMM-SPSI dan pengurus PUK SP RTMM-SPSI.

Undang - undang tidak mengatur tentang penentuan dan mekanisme perhitungan ganti rugi dalam perbuatan melawan hukum. Akan tetapi dalam Yurisprudensi terdapat beberapa kaedah diantaranya adalah bahwa gugatan ganti rugi harus diperinci dan harus dibuktikan dipersidangan. Berdasarkan Putusan Mahkamah Agung Republik Indonesia nomor: 19/K/Sip/1983 tanggal 5 September 2003 juga Putusan Mahkamah Agung Republik Indonesia nomor : 556 K/Sip/1980 tanggal 28 Mei bahwa suatu tuntutan ganti rugi yang tidak terperinci akan dinyatakan tidak dapat diterima dan apabila tidak dibuktikan di persidangan maka akan ditolak. Dalam konsepsi Perbuatan Melawan Hukum, pembayaran ganti rugi didasarkan pada kausalitas dan hubungan langsung antara perbuatan dan kewajiban yang timbul. Berdasarkan Putusan Perdata Gugatan Nomor 226/Pdt.G/2018/PN Blb, hakim menyatakan pembuktian yang dilakukan tidak relevan, yaitu tidak dapat dipastikan hubungan sebab akibat antara kerugian tersebut dengan perbuatan melawan hukum yang dilakukan oleh PUK RTMM-SPSI dan pengurus PUK RTMM-SPSI. Artinya, tuntutan perusahaan kepada PUK RTMM-SPSI dan pengurus PUK RTMM-SPSI untuk mengganti kerugian yang dialami oleh PT. Ultrajaya Milk Industry \& Trading Company tidak relevan sehingga hakim menolak tuntutan tersebut. Terkait tuntutan PT. Ultrajaya Milk Industry \& Trading Company untuk melakukan pemotongan gaji PUK SP RTMM-SPSI dan pengurus PUK SP RTMM-SPSI sebesar 50\% dari gaji yang diterima pengurus PUK SP RTMM-SPSI setiap bulannya selama bekerja di PT. Ultrajaya Milk Industry \& 
Trading Company dalam bentuk mengganti kerugian yang dialami PT. Ultrajaya Milk Industry \& Trading Company juga tidak relevan dan ditolak oleh hakim.

\section{Kesimpulan}

Aspek hukum hubungan industrial dalam penyelesaian sengketa terkait aksi mogok kerja di Indonesia diatur dalam Undang - undang Nomor 13 Tahun 2003 tentang Ketenagakerjaan dan diatur lebih lanjut dalam Undang - undang Nomor 2 Tahun 2004 tentang Penyelesaian Perselisihan Hubungan Industrial. PT. Ultrajaya membawa masalah ini pada Pengadilan Hubungan Industrial dan dalam Pengadilan Hubungan Industrial dimenangkan oleh PT. Ultrajaya Milk Industry \& Trading Company, sehingga adanya aksi mogok kerja yang kedua yang dilakukan oleh serikat pekerja di halaman depan PT. Ultrajaya Milk Industry \& Trading Company. Aksi tersebut menyebabkan kerugian materil yang diderita oleh PT. Ultrajaya kurang lebih sembilan belas milyar yang berujung pada Pengadilan Negeri atas gugatan yang dilayangkan oleh PT. Ultrajaya terhadap PUK SP RTMM-SPSI dan pengurus PUK SP RTMM-SPSI yang sudah melakukan perbuatan melawan hukum dan menyebabkan kerugian. Majelis hakim mengabulkan gugatan PT. Ultrajaya Milk Industry \& Trading Company sebagian yaitu perbuatan yang dilakukan oleh serikat pekerja adalah perbuatan melawan hukum sedangkan perihal kerugian materil yang diderita oleh PT. Ultrajaya Milk Industry \& Trading Company tidak dikabulkan oleh Majelis Hakim. Sehingga PT. Ultrajaya Milk Industry \& Trading Company melanjutkan perkara ke tahap banding sampai saat ini. Sehingga kasus mogok kerja yang dilakukan oleh PUK SP RTMM-SPSI terhadap PT. Ultrajaya Milk \& Trading Commpany sudah jelas termasuk kedalam perselisihan hubungan industrial.

Hubungan industrial akan serasi jika dikembangkan dan dilaksanakan dengan baik, maka dapat membantu meningkatkan produksi, menambah kemungkinan kesempatan kerja, dan lebih membantu menjamin pembagian yang merata dari hasil pembangunan nasional. Di samping itu hubungan industrial ini dapat membantu pemerintah dalam bekerja sama dengan organisasi-organisasi pengusaha serta buruh. Jadi hubungan tersebut berfungsi sebagai motivator untuk menggerakkan 
partisipasi sosial dan menyukseskan pembangunan sehingga tercipta ketenangan bekerja dan ketenangan berusaha. Sebagai pekerja seharusnya mempunyai rasa percaya terhadap pemberi kerja begitu pun sebaliknya. Seyogyanya Pemerintah harus lebih memperhatikan spesifik permasalahan Hubungan Industrial yang terjadi di lapangan. Ada beberapa landasan dalam hubungan industrial yang harus diperhatikan oleh pengawas ketenegakerjaan dalam melaksanakan tugas dan tanggung jawabnya. Penyelesaian perselisihan hubungan industrial melalui Pengadilan Hubungan Industrial seharusnya tidak hanya dibentuk pada ibukota Provinsi saja tetapi sepatutnya dibentuk di seluruh Pengadilan Negeri di setiap Kabupaten/Kota hal ini untuk memberikan pelayanan kemudahan bagi pencari keadilan perselisihan hubungan baik bagi pekerja maupun pengusaha sehingga asas cepat, sederhana dan biaya murah dapat tercapai. Berkenaan dengan Kasus PT. Ultrajaya Milk \& Trading Commpany seharusnya serikat pekerja menghargai dan menghormati proses tripartite terlebih dahulu sebelum melakukan aksi mogok kerja. Juga aksi mogok kerja yang dilakukan haruslah sesuai aturan yang dianjurkan oleh pemerintah mengenai aksi mogok kerja yang sah. 


\section{DAFTAR PUSTAKA}

\section{Peraturan Perundang - undangan}

- Undang - undang Nomor 3 Tahun 2013 tentang Ketenagakerjaan

- Undang-Undang Nomor 2 tahun 2004 tentang Penyelesaian Hubungan Industrial

- Keputusan Menteri Tenaga Kerja dan Transmigrasi Republik Indonesia Nomor: KEP. 232/MEN/2003 Tentang Akibat Hukum Mogok Kerja Yang Tidak Sah

- Peraturan Pemerintah Republik Indonesia Nomor 45 Tahun 2015 Tentang Penyelenggaraan Program Jaminan Pensiun

\section{Buku}

- Abdul Khakim, Dasar-Dasar Hukum Ketenagakerjaan Indonesia, Citra Aditya Bakti, Jakarta, 2009.

- Dedi Mulyadi, Kebijakan Legislasi tentang Sanksi Pidana Pemilu Legislatif di Indonesia Dalam Perspektif Demokrasi, Jakarta: Gramata Publishing, 2012.

- Hardijan Rusli, 2011, Hukum Ketenagakerjaan, Ghalia Indonesia, Bogor.

- Imam Soepomo, SH.,Prof.,'Hukum Perburuhan Bidang Hubungan Kerja”, (Penerbit Jambatan, 1975. Jakarta.

- M. Yahya Harahap, Beberapa Tinjauan Mengenai Sistem Peradilan dan Penyelesaian Sengketa, PT. Citra Aditya. Bandung, 1997.

- Libertus Jehani, Hak - hak Pekerja Bila di PHK, Visi Media. Jakarta,2006.

- Naskah Akademis, Penyelesaian Perselisihan Hubungan Industrial, Puslitbang Hukum dan Peradilan, Badan Litbang Diklat Kumdil, Mahkamah Agung RI, 2007.

- Payaman J. Simanjuntak, 2009, Manajemen Hubungan Industrial, Jala Permata Aksara, Jakarta.

- Prof.Dr.U.Wiyono, Dalam hal ini Sebagai Nara Sumber Penelitian.

- Ugo, Pujiyo. Hukum Acara Penyelesaian Perselisihan Hubungan Industrial.

- Abdul Jalil, Teologi Buruh, LKIS Yogyakarta, Yogyakarta, 2008. 
- Sumanto, 2014, Hubungan Industrial, Cet. I, Center Of Academic Publishing Service, Yogyakarta.

\section{Internet}

- Adi Haryanto, "Rugi Rp19 Miliar Akibat Demo, PT Ultrajaya Menang di Pengadilan", https://jabar.sindonews.com/berita/4670/1/rugi-rp19-miliarakibat-demo-pt-ultrajaya-menang-di-pengadilan.

- Cecep Wiajaya Sari, “Ganti Rugi Rp 19 Miliar Ditolak, PT Ultrajaya Ajukan Banding”, https://www.pikiran-rakyat.com/bandung-raya/pr01312091/ganti-rugi-rp-19-miliar-ditolak-pt-ultrajaya-ajukan-banding.

Riska Fitriyani, Proses Mediasi di Kabupaten Slak, Jurnal Ilmu Hukum, Vol. 3 No. 1, Tahun 2013, Pekanbaru: FH Universitas Riau, ejournal.unrl.ac.id/index.php/JIH/article/.../1024. 